\title{
Need-Based Street Children Management in Surakarta City of Central Java Province of Indonesia
}

\author{
Argyo Demartoto ${ }^{1}$ \\ ${ }^{1}$ Department of Sociology, Faculty of Social and Political Sciences, Sebelas Maret University, Surakarta, \\ Indonesia \\ Correspondence: Argyo Demartoto, Department of Sociology, Faculty of Social and Political Sciences, Sebelas \\ Maret University, Ir. Sutami Street 36 A Kentingan, Surakarta 57121, Indonesia. Tel: 62-271-637-277. E-mail: \\ argyodemartoto@ymail.com
}

Received: May 3, 2012 Accepted: May 25, 2012 Online Published: August 17, 2012

doi:10.5539/ass.v8n11p107 URL: http://dx.doi.org/10.5539/ass.v8n11p107

\begin{abstract}
The objective of research is to find out the characteristics of street children, the cause of children becoming street children, and the management of street children problems in Surakarta City. As the marginalized and alienated children from the hard environment of city, the some street children living and working in the street, work in the street but still return back to their parents' home everyday, then some of them work in the street and return back to their origin once in $1-3$ months and the problematic street adolescents disperse in a variety of certain zones because of poverty, domestic violence, parents' encouragement, and children's environmental factor. The management of street children is determined by the need and problem the street children is facing whether using street based with street literacy, centre based and re-socialization through the open house for street children as well as community based approaches by conducting activity and advocacy on the street children problems involving all potencies of society. In fact, the approaches above are overlapping. The most important point is our empathy and commitment to manager the street children problem.
\end{abstract}

Keywords: street children management, need based, street based, centre based, community based

\section{Introduction}

Bearing a predicate of Reasonable-for-Children City is the pride for Surakarta City, and the challenge all at once for the Surakarta City's government. It is because the children problems in Surakarta City are still high in number and varied. One of them is street children issue. Street children issue is identical with the children issue in urban areas including Surakarta City. In Surakarta city there were 120 street children in 2006 consisting 101 male and 19 female. In 2007, there were 96 street children: 80 male and 16 female, while in 2008 there were found 50 street children: 36 male and 14 female. In 2009 there were 51 street children: 43 male and 8 female.

There are so many problems threatening the existence of street children because they basically are the marginal children in urban area undertaking dehumanization process. They not only should be able to survive in a hard unfriendly city life circumstance not conducive to the children growth, but also they tend to be alienated by the society, become object of exploitation by many parties such as peer, criminal or irresponsible apparatus, exploitation target, rape victim and any other kinds of oppression.

Data on street children is dynamic and fluctuating recalling the street children nature having sufficiently high mobility level so that no definite data on that matter. Nevertheless, many data exist to which the street children management program can refer. Collecting data on street children is very important in the attempt of solving the children problem ending up in the fulfillment of children right; moreover the street children problems in Surakarta City are increasingly varied, in both quantity and quality. It should attain serious attention from the government, non-government organization (NGO) and society. Considering the children as a nation's asset, the Government of Surakarta City is obliged to ensure the quality of their growth and to give them protection and their rights according the constitution and Republic of Indonesia's Act Number 23 of 2002 about Child Protection as the implementation of the Right of the Child and to build a comprehensive child protection system.

Based on the background above, in order to create the awareness and understanding of the street children 
existence, a research and analysis on this problem is carried out in Surakarta City. The objective of research is to find out the characteristics of street children, the cause of children becoming street children, and the management of street children problems in Surakarta City. The result of research can be used to develop a need-based street children management model and to formulate an appropriate intervention program.

\section{Literature Review}

UNICEF defines "Street child are those who abandoned their home, schools, and immediate communities before they are sixteen years of age have drifted into a nomadic street life" (UNICEF, 1997). UNDP and Republic of Indonesia's Social Department define street child as those spend their most time to earn money or to stray on the street or in other public places (UNDP \& Departemen Sosial Republik Indonesia, 1997). Street child is "an individual less than 18 years old spend some or all of his/her time by carrying out activities to earn money or to survive". Meanwhile the definition of street children not only refers to the street but also to other places like market, shopping center, City Park, square, bus terminal, station, and etc. (Shalahuddin, 2004).

Overall, the street child is divided into three groups. Firstly, children on the street are those having economic activity as the child worker on the street, but still having close relationship to their parents. Some of their income is given to their parents. The function of street child in this category is to help reinforce their family's economic support because poverty burden or pressure they should bear on cannot be solved by their parents alone. Secondly, children of street are those who participate fully on the street, either socially or economically. Some of them still have relationship to their parents, but their meeting frequency is not certain. Some of them are those who because of any cause (usually violence) escape from home. Various studies showed that the children in this category are very vulnerable to mistreatment, whether socio-emotionally, physically or sexually. Thirdly, children from families of street are those coming from the family living on the street. Although these children have strong kinship, they should be lost about from one place to another with any risks (Irwanto. dkk, 1995; Suyanto, 2010).

Generally, there are three factors causing the street children problem emerge. At micro level, the cause can be identified from the related children and family and also the independent cause: escape from the family; asked to work after school or have been dropped out, adventuring, playfully or asked by friend. At mezzo level, the cause derived from family such as neglected, parents' incapability of providing basic needs, rejected by parents, mistreatment or domestic violence, difficulty of communicating with family/neighbor, separated from parents, wrong attitude to the child, limitation of child caretaking leading the children to have physical, psychological, and social problems. Meanwhile at macro level; the cause identified includes: in poor people, children are asset to help family improvement, they are taught to work leading to dropping out of school, while in other society, urbanization becomes habit and the children follow it, the society's rejection and assumption that street children is the prospect criminal (Mulandar. ed, 1996; Saripudin, Suwirta \& Komalasari, 2008). Generally, neglecting and arbitrariness against the children, in addition to relative to their family's poverty, is also related to the parental rejection. Narrol (1983) suggested theory of parental rejection, the one explaining the neglecting against children. He also explained that father or mother who rejects children is related to the low moral support of society to such the family because they are trouble people (Lewis, 1996).

One right of children, including the street children, is to enjoy education, but education sustainability for the street children generates apprehension (Warsono, Gunarto \& Suyanto, 2011). Meanwhile, education is the means of preparing the children to live within the society (Durkheim, 1956; Ballantine, 2001) In education sector, there is a concept of formal education with a systematical and multilevel activities; informal and non-formal education (Faisal, 1987).

Durkheim suggests that education has different tone from one society to another, from one age to another. But in addition to such difference, there is also similarity in which education plays a part in bringing about and in maintaining the social order and social equilibrium (Durkheim, 1961). In addition, education plays a part in socialization, selection, distribution and social integrity processes. Society holds a dominant position in creating an individual into a member of society. Parsons and Bales see education as the socialization and selection functions holder. However, out of those two functions, the one more emphasized is socialization function encompassing value, cognition, and motor aspects. Among those three aspects, there is a consensus that value is a factor presupposed to the emergence of and maintenance of social integrity. Through socialization, the cultural value the society has is converted into the applied or internalized one by the member of society individually (Parsons \& Bales, 1955).

Blackledge and Hunt explains that Durkheim's education model gives dominant position to the teacher as the representative of state, nation and adult in preparing the young generation that can contribute as the complete 
member of its society. Otherwise, he put the students in the created position. In this way, homogeneity and the society sustainability as well as social order is maintained. The balanced society, all members of which have collective consciousness, is an ideal one. Education functions and serves to create consensus over this values. (Blackledge \& Hunt, 1985; Adiwikarta, 1988). Education should be applied consistent with the characteristics of society or community including the street children in order that the education can function and play a role in the society, particularly, in coping with the street children problem. In the presence of education, it is expected that the street children can play a role in bringing about and maintaining social order and social equilibrium (Usher \& Edwards, 1994; Silva, 1996).

The increasing number of street children population due to economic crisis leads to an increasingly worrying street children problem development. Street children face a situation in which their rights as child are getting reduced, whether in education, life sustainability, growth, or protection aspect. Street children are very vulnerable to the negative effect of environment on the street. Thus, many of them have social deviation, street children is frequently identified as a free, wild, incompliant with rule child committing negative activities such as stealing, quarreling, drunk, drugs abusing, involving in free sex, and etc (Berman, 1996).

Coping with the street children problems is not easy. So far, many attempts have been done, by both Non-Government organization, government, professional organization, and social organization, and personal individual to help the street children get out of or at least relieving their from their anguish. However, since all of them are carried out temporary, segmentary, and separately, the result is less maximal. For the street children management, protection attempt and empowerment to provide better outcome, all parties are required to meet, and discuss to get the best solution for the street children, and then to formulate an appropriate intervention program and to coordinate the job division.

There are many approaches the government, non-government organization, and society usually use in handling the street children. (Mulandar ed, 1996; BKKKS Provinsi Daerah Istimewa Yogyakarta, 1996; Saripudin, Suwirta \& Komalasari, 2008; Suyanto, 2010). Firstly, street-based approach is the street children management model in the place where the street children come from or live, then the street educators come to them: dialoguing, accompanying them working, understanding and accepting the situation, as well as positioning themselves as friends. In several hours, the children are given education material and skill; in addition the street children also obtain relation and affection warmth that can grow mutual trust that is useful for the achievement of intervention objective. Here, the approach principles used are usually, "asih, asah, and asuh (love, teach, and care for)".

Secondly, the centre-based approach is the street children management in institution or house. The children entering this program are accommodated and given service in institution or house such as given meal and protection in the night, as well as warm and friendly treatment from the social workers. In permanent house (panti), even education, skill, basic need, health, art, and work services are available for the street children. In the management in institution or house, there are several accommodation types or models: drop-in centre and residential centre. The street children who still go to and fro the street are usually included in drop in centre, while those who have actually abandoned the street will be included in residential centre. The social service method the governmental institution or non-government organization uses is to give service in order to meet all children's basic needs, both physically and psychically, including food, clothe, residence, education, recreation, health and etc. The service through house system is directed to the learning process occurrence as the education should be in an intact family, because the house is an institution playing a role as an alternate family.

Thirdly, community-based approach is the management model involving all potencies of society, particularly the street children's family or parent. This approach is preventive in nature, that is, to prevent the children from being caught up in street life. The family is given education about the children nurturance and the attempt of improving their standard of living; meanwhile the children are given opportunity of obtaining formal and informal education, spending leisure time, and other useful activities. This approach aims to improve the family's and community's capability of protecting, nurturing, and meeting the children's needs independently.

The existence of children on the street indicates the child social malfunction. The social functioning concept refers to the child situation and relation bringing about role and duty. A child should be in home situation, school, and playing environment, in which they interact with others in such the situation and have such specific role as learning, complying with mother and father, playing, and etc. The condition of earning money or straying by spending most time on the street clearly deviates from the child's social functioning (Mifflen \& Mifflen, 1986; Blerk, 2006; Saripudin \& Ahmad, 2007). For that reason, the RI's Social Department sees the street children as the problematic ones, because of many situations, relations, and roles they cannot do. For that reasons, the street 
children need a specially and seriously management. (BKKKS Provinsi Daerah Istimewa Yogyakarta, 1996; Departemen Sosial Republik Indonesia, 1999 a; Irwanto, Farid \& Anwar, 1999). The outcome of street children management is the street children's social functioning within the society consistent with the human being's dignity.

\section{Research Methods}

This study is an evaluation study. It is aimed at assessing a program, activity or policy intended to intervene with the community. The evaluation research is intended to give feedback in order that a program, activity or policy exerts an effect as expected. Evaluation has three main focuses: to assess the program conceptualization, program implementation, and effect of a program (Denzin \& Lincoln, 2000). This research wants to find out the implementation and the outcome of three approaches to street children problem management in Surakarta city.

The research was conducted in Surakarta City. The informants of research consisted of: providers of service for street children, stakeholders related to the street children management program in Surakarta City, both government and non-government organization, and the user of street children and family service. The sampling technique used was purposive sampling referring to the objective of research. The data type used in this study consisted of primary and secondary data.

Techniques of collecting data used for primary data were semi-structured interview, focus group discussion, and observation. A variety of data collecting instruments was used to obtain valid data concerning the data and information given by the informants. Meanwhile techniques of collecting and analyzing secondary data used were library study (narrative analysis), policy document, statistic data available in institution/service relevant to this study, and other literature source such as electronic media (internet).

\section{Result and Discussion}

Surakarta city is one of big cities in Central Java Province of Indonesia supporting other cities such as Semarang and Yogyakarta. Surakarta City is $40.04 \mathrm{~km}^{2}$ in width. There are 5 sub-districts and 51 kelurahans. The number of Surakarta City's population in 2010 was 532.439 people. The number of 0-19 years old children was 145.758 (in 2010). This number is $\pm 27 \%$ of Surakarta city's total population. The implication of such the data is the stakeholders realize that $27 \%$ of Surakarta population is children who deserve obtaining protection from adult.

Based on the data obtained from Surakarta City's Social Labor Transmigration Service (Dinsosnakertrans) in 2010, there are 30 street children: $80 \%$ male and $20 \%$ female.

\subsection{The Characteristic of Street Children in Surakarta City}

Considering the result of research, it can be stated that in Surakarta city there are several street children groups. The first is the street children group that lives and works on the street. They spend all of their time on the street; living in small group or individually; sleeping in the spaces/cavities in urban areas, such as terminal, store porch, under the bridge and shopping centre; the relationship with parent has been usually broke; drop out; working as rubbish collector (pemulung), street musician (pengamen), beggar, shoe polisher; porter; nomadic.

The second is the one that works on the street and still goes back their parent home everyday. Their relationship with parent still exists but is not harmonious; some of them come from slump and poor urban areas; some of them have been dropped out and the rest is vulnerable to abandon the school; going back home every day or once a week, on the average; working as: beggar, street music in intersection, assistant driver, pedagang asongan (the trader who vending their merchandise on the bus, train, etc) and umbrella renter.

The third is the one working on the street and going back their village once in $1-3$ months. Working on the street as: pedagang asongan, food vendor, porter; living in group along with those who come from the same area by means of hiring house or living in public/worship facilities such as mosque; going home once in $1-3$ months; contributing to their family living in the village; drop out.

The fourth is the problematic street adolescents. They spend some of their time on the street; some of them have been dropped out of school, get involved in drugs and psychotropic abuse; some other get involved in free sex; some girls are pregnant and vulnerable to getting involved in prostitution; coming from disharmonious family.

In Surakarta city, the existence of street children is generally dispersed in various zones or certain zone, or place or location in which the street children carry out their activities including working. The children do not only their activities on the street without direction but also economic activity such as becoming street musician, selling some items (mengasong), begging, market porter, polishing shoe, parking car, being assistant driver, prostitute, ticket scalper, umbrella renter, car washer, and straying without direction. Such the activities are generally done in public places, such as street intersection, terminal, station, market, entertainment centre (theater), plaza or mall, 
City Park, rubbish disposal place, localization place, gas station, grave, station, and etc.

There is an interesting finding in this research. It is that in fact, on the street, the street children find freedom, pleasure and all of their wants. They freely enjoy any facilities existing on the street and do any activities they want. With such the freedom, they develop behavior corresponding to the street culture they deal with. In addition, the life on the street is characterized by the street children groups consisting of the children in the same age and same development level as well as same interest and capability.

The base location of street children in Surakarta City include in Kerten Intersection, bus stop of Kerten UNS Campus, Manahan Intersection, Sumber Intersection, Joglo, Tirtonadi Bus Terminal, Ngemplak Intersection, Panggung Intersection, Pucang Sawit, Jebres Station, Balapan Station, Purwosari Station, Baron, Sriwedari, Masjid Agung, Klewer Market, Sangkrah Intersection, Gladak Intersection, DKT, Mangkubumen Intersection, Fajar Indah Intersection, Pasar Pon Intersection, Jurug, Kentingan UNS Campus Bus Stop. Viewed from their origin area, the street children come from Surakarta City, Karanganyar Regency, Boyolali, Sragen, Sukoharjo, Klaten, Wonogiri, Grobogan and DKI Jakarta province.

\subsection{The Factors Making the Children the Street Children}

There are several factors making the children go to the street and spend most or all of their time to undertake economic activities and decide to live on the street leaving their family and community. It is revealed from the data and information in the field.

Poverty becomes the root of the street children's existence. Economic burden befalling the family forces them to work earning money and sacrificing their childhood to help their family. The children from poor family tend to have higher risk of living as street children than those from the rich family. The economic social pressure and parent's helplessness become one reason for them to go down the street and help their parent meeting their family's life needs. Majority street children in Surakarta indeed come from the poor family.

Meanwhile, there are some street children stating that violence within the family become one factor making the children prefer to stay and live on the street. The child has large potential to be exposed to violence occurring in a family. The ignorant child tends to become the target of parent's or relative's violence. The domestic violence is not only physical in nature, but also mental and sexual in addition to economic exploitation factor.

Some children go down to the street because of parent's encouragement, in which the parents exploits their children to look for money. The parents frequently require their children to deposit some money daily. Here is a child's helplessness facing their parent's authority. Poverty and family breaking are closely related, recalling that poverty a family experience will result in family fissure. In this case it will affect the child. The child becomes neglected and gets less attention. The child frequently becomes the target of parent's emotional release.

In addition to some factors above, there is still a factor highly affecting the child to go down the street, namely child environment factor. The child usually living in slump environment in which many children and adults do activities on the street can be affected and motivated to follow them doing so. It can be initiated by jointly hanging out in one community or sharing between one child and another. For Example: in the area of Kalianyar bank (Nayu Barat, Minapadi, Praon, Sumber).

\subsection{Need-Based Street Children Management Model}

When we observe the factors making the children on the street to live and work as mentioned earlier, it can be found that the complexity of street children life is not a static but dynamic. The ways they use to survive develop over time, both individually and in group, as an interactive process with the change of social, economic, cultural, and political life environment in urban areas. However, we, as the one who pay attention to and concern with them, sometimes forget and pay less attention to the dynamic adaptation process of street children group. Such condition is reflected on the characteristics of program to cope with street children problems in Surakarta City.

\subsubsection{Street-Based Approach with Street Literacy}

One basic assumption most frequently coloring a variety of street children management program in rural area is to consider them as disable person who needs pity. The philosophy of street literacy is intended to improve and to build the street children's survival capability, both individually and in group. Street literacy does not cover up the capability, daily activity or knowledge the street children have acquired. Street literacy departs from the existing capability, skill, want, and condition of street children to reinforce the children's potential and opportunity of learning and developing. Street literacy is not only "literacy" in reading and writing sense. Rather, street literacy is an individual's capability of living, learning, working, playing and developing on the street. Street literacy is the capability, skill, knowledge and friendship needed by the street children to cope with risk, 
deal with challenge and develop themselves, both individually and in community in which they belong to (on the street, at home, learning house, school, work environment).

In Surakarta city, the street literacy process was started from Bina Bakat NGO since 2005 by building the street children in the location of them (street-based activities). There are 17 children built: 10 male and 7 female. The need of street children found in the street-based activity, in fact, develops. Even some of them need more permanent and periodic activities; some others need those with advanced prospect, in both education and skill fields. The management of increasingly developing need and activity encourages Bina Bakat NGO to establish the street children building into the Learning House. Some children who want to obtain advanced education and skill finally begin their new activity in the Learning House, while some others keep with the street-based activity.

Street literacy program can be categorized into three child needs. The first is self development. The learning activity and process, invite the children to develop their capability of guarding and taking care of themselves (physically, emotionally, mentally), of having intercourse fairly with their peer and wide society, and of improving their "thinking-reading-writing-drawing-designing something-moving-creating- skill.

The second is self protection. It is done through some exercises to strengthen themselves physically (exercise, self-defense practice) and discussion to understand better the rights and to cope with violence on the street. The self protection aspect involved local people, particularly apparatus, security guard, police officers, civilian, local public figure, and advocate (and law aid institution) to guard and to support the existence of children during on the street.

The third is skill and work development. It is done through wood, batik, music, typing, handicraft, drawing, silk-screening, media writing, business lessons, and etc, by inviting the children find their aptitude/interest and develop their skill. In addition to skill, it also invites the children to study and to work in group, to design something, to manage money (capital, profit) and entrepreneurship. All lessons help children prepare themselves to enter into and to determine their fate in work realm in their adolescence and adulthood.

To implement the street literacy program, Bina Bakat NGO prepares several components. Firstly, street educators. In addition to children, those who are very important in street literacy program are street educators or street children assistant. Bina Bakat NGO has 3 street educators. The assistant serves as friend, elder brother/sister, god mother/father, caretaker, teacher, defender, and supporter all at once for the children. The more important thing in the assistance, however, is the friendship and trust between the assistant and the children. The most appropriate way for the children, in addition to friendship, is the role of assistant as the role model for the children.

Bina Bakat NGO supports the street educators or assistants with some offerings, such as: support for full-time work; work recommendation, weekly and monthly schedule, agreement, transportation cost, institutional support, assistant education and salary. The offering of being assistant is in full-time work (can be 24 hours $\mathrm{x} 7$ days without leave). The opportunity of staff development (training, seminar, skill learning, study travel, apprenticeship, discussion) along with the development of street literacy curriculum while the program runs (consulting other assistants, reading sources, consultation with alternative education advisor) as well as supporting and helping develop network between the assistant both inside and outside Surakarta City.

Secondly, material and curriculum. Up to now, the appropriate material and curriculum that supports the development of street children development is still limited in number. So, while the street educators invite the children as friend, the should also prepare the material and lesson in street literacy units or module. The street educators can develop material because they are those who are closest to the children and familiar with their needs as long as there is time to plan, to write, to record the (either successful or failed) result and to revise the plan. When the educators follow the process over one topic (e.g. street music or daily life or money management), several weeks later, one unit or module of daily hygiene or street literacy module will result. Such the experience can be printed and delivered to other street educators as the appropriate source of education that supports the street children development. The children can expand the learning material (Learner Generated Materials or LGM), namely a child's story that can be made learning material for other children. It can be collected and be made street children magazine or newspaper. During designing the learning material, what should be remembered are the children need and the question to themselves "what do the children get from the learning?" So, not only acquiring knowledge, but also understanding, healthy behavior, friendship, capability of having intercourse with wide society and opportunity of creating and expressing themselves.

Thirdly, in the Learning House, two or three activities are attempted to hold a day including informal school, creativity, drama, child music, band music, typing, library, batik, health, self-defense, football, discussion with physician and legal expert, money management business development, recreation, and etc. The delivery way and 
methodology is not like that used at school, in which the teacher stands in front of many children and speaks (and the children sit down, are silent, listen to). Once, learning can be done in discussion form, in traveling, on the way to the market, through talking, writing, drawing, story, singing that is done both individually between an educator and a child (one to one) and in group. It can also be done in the morning, day, evening or night. It even can occur from morning to evening, or during waiting for the city bus coming to the bus stop. Generally, the Street Literacy methodology is an way of making the children have big role, as interactively as possible.

Fourthly, the Learning House. Learning House is an organization for street children in which they assemble, learn together, and meet with street educators. This house is located amidst the slump kampong, so that the children can learn by becoming the part of urban society (socialization). Some children live and sleep in the Learning House and becoming "big family", and manage their household (socialization). What important is openness circumstance in order that the street children who come from inside and outside Surakarta can come, assemble with their peer, develop something collectively and follow several (prescheduled) activities.

A Street educator of Bina Bakat NGO states that the outcome of street based approach with street literacy is that the street children he builds and educates are no longer on the street but work in informal sectors such as food stall waiters, band players, security officers, computer typist, and silk-screening (printing) service.

\subsubsection{Centre-Based Approach with Street Children Re-Socialization through the Open House for Street Children}

Street children is frequently identified as a free, wild, incompliant with rule child committing negative activities such as stealing, quarreling, drunk, drugs abusing, glue inhaling, involving in free sex, and etc. Such the condition occurs because their relationship with parents is loose or even broke in some case. They are on the street with no control and attention, even some of them are expelled by their parents or deliberately leave from home. Living without parents enables the children to do anything freely. The effect of street and friends on the street makes the personality gradually adapt to the life of people on the street. The longer are the children on the street; the strong is the effect on his attitude and behavior. The attempt of restoring the children's attitude and behavior to the social norm is very important to con through re-socialization activity. Re-socialization emphasizes on the change of children's attitude and behavior that should be carried out before the empowerment program applied to them. Re-socialization provides knowledge, awareness growing, and strength for self-capability in dealing with daily life and solving problems (Horton \& Hunt, 1984; Faisal, 1987; Nasution, 2004; Saripudin, Suwirta \& Komalasari, 2008).

For that reason, the objective of street children re-socialization is to make the street children have good and positive attitude and ideology, exhibit right social behavior, have self-governing capability and life difficulty coping capability. In re-socialization to the street children, the tutors used friendship and equality principle. Despite children, the experience on the streets had made them mature. Re-socialization avoids instruction pattern and gives ongoing inputs in which the children are the object. The street children are put as the subject of the change occurring to themselves. The prevailing principle is that the tutors cooperate with the street children discussing to formulate activity, to give deliberation, and to inspire the selected attempt. In the end of re-socialization, the street children are expected to be able to help themselves (Hariadi, Sanituti \& Suyanto, 1999; Saripudin, Suwirta \& Komalasari, 2008).

Based on the Street Children Building Organization Guidelines through the open house for street children (Rumah Singgah) of Republic of Indonesia's Social Department in 1999, the Surakarta city's government, in this case the Social Office of Surakarta City had conducted several activities in the street children resocialization. Firstly, the general/daily social counseling consists of daily attitude and behavior such as: personal hygiene, selecting food and table manner, maintaining health, speaking politeness, literacy, religion, house hygiene, relationship with father and mother, relationship with friends, relationship with neighbor, work safety, role induction, recreation, discussion, and tenets about the society norms. Secondly, case counseling is the one for coping with the difficulty in the street children life, consisting of avoiding, reducing, and stopping smoking habit, liquor drinking, drugs abuse, glue inhaling, free sex, leaving from school without permission, quarrelling, stealing, resenting and hostile to friends. The street children re-socialization is conducted in any time particularly when there is a problem or something requiring counseling. General/daily counseling is conducted everyday continuously. The case counseling is conducted to the problem emerging and the period of management depends on the problem the child faces, may be short or long when the case is severe problem.

The methods used in the street children resocialization are consistent with the technical instruction of Republic of Indonesia's Social Department for the Implementation of Street Children Social Welfare Building in 1999: 1) personal social counseling is the one with the child personally or one by one, for both general and case counseling. 2) Group social counseling is the one conducted in group in the term of providing 
material/information to all children or counseling with the child sharing the same problems. 3) Home visit is to visit and to guide the children in their family and to involve the parents or other members of family. The counseling and learning use discussion technique, advising, socio drama, role playing, quiz and test, reward and punishment, writing, telling story, motivating, advocating, information providing, exchanging experience and expressing feeling. Themselves (Saripudin, Suwirta \& Komalasari, 2008).

The Social Service of Surakarta City established "Wanita Utama" Surakarta I and "Bhakti Chandrasa" Surakarta II of Social Rehabilitation Office in Jl. Dr. Rajiman 622-624 of Surakarta to give social service and building to the elders, disabled, mischievous child, violent crime victim as well as vagrant, street child, prostitute, and prostituted child caught in the street raid. To cope with the street children problems, the Social Service of Surakarta City also conducts re-socialization of street children through open house for street children. The Social Rehabilitation Office become the open house for street children for the street children in Surakarta City. There are \pm 25 street children fostered in the half house. The open house for street children is a special social service model for street children providing circumstance enabling the learning process to occur, and as the early stage for the next stages. Meanwhile sahabat anak (children best friend) car is the means used to provide service to the street children by visiting them directly to their activity centers, aiming at maintaining and giving positive attitude and behavior reinforcement to the street children. The sahabat anak car will be able to reach the street children in a wider area the open house for street children cannot reach.

The general objective of open house for street children is to help the street children cope with their problems and determine the alternative life need fulfillment. Meanwhile the particular objectives of open house for street children are: (a) to reestablish children attitude and behavior consistent with the values and norms prevailing within the society, (b) to attempt to bring back the children to their house if possible or to the orphan or other alternative institution, if necessary, and (c) to give a variety of alternative services to the fulfillment of children need and to prepare their future to become productive and independent members of community (Departemen Sosial Republik Indonesia, 1999a; Saripudin, 2012).

In achieving its objective, the open house for street children functions as: the place where the social workers meet the street children to create friendship, assessment and to undertake program activity. It also functions as the street children's need and problem assessment center as well as making social service referral for the street children. It is an intermediary between the street children and the family, house (panti), alternate family, and other institution. The street children do not depend on the open house continuously, but obtain a better life after the process they undertake. The open house for street children (Rumah Singgah) is considered as the place for the children to be protected from any kinds of violence, sexual abuse, economic abuse and other forms occurring on the street. In addition it also provided a variety of information on many things relevant to the street children interest such as data and information, job fair, education, skill course and etc. The open house also has curative and rehabilitative functions (restoring and implanting social function into children). It means that the social workers are expected to be able to cope with the street children problems and to correct their daily attitude and behavior that eventually will be able to grow children social functioning. The professional ways or interventions conducted for this function include to employ a counselor corresponding to the problems. As the stop-over place, the open house provides access to various social service and other source systems, aided by the social workers. Finally, it functions as re-socialization meaning as the attempt of reintroducing norm, situation and life within the society to the street children and leading to the member of society's recognition, responsibility and attempt of managing the street Children. (UNDP \& Departemen Sosial Republik Indonesia 1997; Departemen Sosial Republik Indonesia, 1999a; Saripudin, 2012).

The attempt of street children management in Surakarta City was conducted in 5 stages. The first one is reaching. Reaching is done by the social workers to the street children activity centre, aiming to establish preliminary contact and to grow confidence among the children in the social workers and to socialize the alternative semi-institution education, so that the street children have willingness and capability of attending the learning in the open house.

The second stage is Assessment. Assessment is conducted after the children enter the open house to find out the problem (problem assessment) and to find out the learning need the children face including their motivation in attending the learning. The problem and learning need can be referred to in formulating the learning strategy and process to be conducted in the open house.

The third stage is Learning Preparation. From the result of learning need assessment, the children and the officers (social workers, tutors, principal) of the open house participate in formulating the objective, time, material, method, strategy, infrastructure, media, and learning evaluation collectively based on the convenient 
circumstance. All of these are supported by the rule of thumb prevailing in the open house through agreement (working agreement) between the officers and the children, and between the child and another one.

The fourth stage is Learning Implementation. In learning implementation, the social worker or tutor serves as the facilitator who facilitates the children in obtaining their needs, both knowledge ownership and skill ownership needs as well as guide them in solving the cases they face through the children potential empowering.

The fifth stage is termination. Learning termination is done after the need becoming the children's objective has been achieved, with productive and independent indicators, come back to their parents, alternate family, admitted in panti/pesantren (school of Islamic studies for children and young people) or obtaining better job.

The executives of the Open House consist of principal, social workers, administration officers, and chief of street children community. In addition the fixed executives, there are also temporary executives such as tutors who conduct skill training the street children need, nutrition consultant, psychologist, physician, religion teacher, police officers and etc as necessary. The guiding and learning activity is done more by the social workers, during both on the street and in the open house. The ratio of social workers to street children is 1:15.

The infrastructures of the Open House consists of the room for assembling the street children, the room for the management, room for the chief of street children group, the room for storing the children's clothes and goods, kitchen, bathroom, playing room and clothe sunbathing place. The equipment of the open house consists of cleaning tools, appliance, playing instrument, learning instrument, printed media and electronic media.

The open house's source of fund derives from the government both central and local and grant from foreign countries or international institution (WHO, UNICEF, UNESCO, UNDP), local NGO or foreign NGO, contribution from community and business realm. The social workers who give some street children the social counseling in Surakarta city, this outcome of approach can be indicated by the street children's social behavior who are motivated to attend the silk-screening training, to be discipline, decorous, religious, to have some skills to work in the workshop, to type using computer and to work in cleaning service.

4.3.3 Community-Based Approach by Conducting Activities and Advocacy Concerning the Street Children Problems

The activity and advocacy attempt the Bina Bakat NGO takes is more local in nature and through individual, rather than national and through juridical or legal channel. Nevertheless, Bina Bakat NGO remains to support the advocacy nationally to realize the UN's convention, remains to discuss about the Convention problem with their built children. In advocacy attempt, this organization involves many people such as local community, parents or origin family, assistant, and street children. The core or idea of advocacy attempt is to try bridging some misunderstanding about the street children, to improve positive matters (such as, the role of children within the family, creativity, merit), and to lobby for certain need, such as education.

Several forms of advocacy the Bina Bakat NGO has done include: advocacy with the local community that is done in daily interaction and the local community participation in the activity, in both Learning House and 'hanging out' place/workplace of the street children, for example: the assistant can be recruited from the local community and adolescent; holding special activity (such in Holy Day) with the local community and the street children's parents; the street children's and the assistant's participation in local activity and event, voluntary labor service (kerja bakti), cooperation with the neighbor in the project of repairing the kampong and inviting the local community into an activity with the children or inviting them to the learning house and discussing the role of assistant in order to understand better the children.

One of informal advocacy forms is by interacting and getting involved in several children's families through home visiting (when the children still have family and when the family wants to know the activity of Bina Bakat NGO). The activities conducted in such visit include: the assistant can lobby the parents and if necessary, protect the children from the violence and exploitation they encounter at home; and the assistant can invite the parents to the Learning House (if the parents still care about their children's fate and activity), the parents can be a part of solution to the children problem.

The street educators can open the way for the children to speak independently or represent the children in certain occasion. The street children need advocates (brother, adult) in the context of and in certain audience.

The street children can voice publicly and to the common society (becoming advocate for themselves). Street educators help the children to prepare themselves and to create several media jointly, such as: article, play/theatrical performance, music band, bazaar, handicraft development and selling in the public market, picture and photograph (children's work) and children's story/experience. Having been created and practiced, the media can be printed, duplicated and distributed to the society widely. Advocacy the street children conduct is the very 
effective attempt and have good side effect (the children can express them self, self confidence, develop their community, typical characteristic and culture of street children).

Because the street children management program focuses on education, Bina Bakat NGO also conducts several advocacy attempts such as: improving several successes and offering the program to Dikpora or existing education institution; promoting idea to the public that working is a part of life, and life is a part of education process $($ working $=$ life $=$ education $=$ experience); accessing formal education program $($ school or BLK/working training bureau or skill practice) when the children want to attend the formal education; and attempting to make the street literacy education program recognized by the local and national education institution. In order to cope with and to help the street children, Bina Bakat NGO establishes good cooperation with local institution, non-government organization, as well as local and national governments. The result of this approach can be indicated by the street children's family and community surrounding who always protect, care and do not neglect the children, do not commit violence against the children, and who meet their children's need.

\subsubsection{Critical Study on the Street Children Problem and Management}

Street children belongs to a group of children that encounters many daily personal problems on the street and the problem coming from both family and street where they live. The risks the street children face include that of being sexual and economic exploitation victim, physical mistreatment, traffic accident, arrested by the police officer, criminal victim, and drug abuse, conflict with other children, engaged in law breach, either intentionally or unintentionally (Berman, 2000). Such the condition of risk on the street is similar across developing countries. In Brazil, the street children "were killed" because they were considered as the chain of narcotic abuse network; in addition, they were also considered, by the government, as the unbearable economic burden. In Surakarta city, many citizens reject them because they have no identity card. Within the family, they encounter economic violence so they should work to earn money and some of them even encounter physical violence. Parents' attitude is refusing, unfriendly, aggressive, uncaring or neglecting. Despite some problems and difficulties, the street children are still not different from their peers.

Street children also have hopes and aspiration. From the elaboration above, the street children seem to be the victim of larger problems surrounding. To ward off that, however, the street children could not do much because those problems beyond their reach. For that reason, it is reasonable when the management of it also involves the society in surrounding environment, whether family, friends, or other influencing people. With intervention of the society surrounding, it will be difficult for the street children to get out of difficulty environment. The researchers say that the group of street children is the unique one, because they can survive amid the big problems and risks on the street. Many street children get the lesson from the street, from which they learn and understand quickly so that their potential can be expressed well naturally. But, some street children even intentionally make the street a means of learning to subjugate the street life.

This positive aspect the street children have is very important to consider particularly in managing and empowering the street children. This management of street children should consider the varying street children, so that it makes the street children management model always different and adjusted with its condition. The three approaches to street children management are overlapping. The activities commonly conducted are: social counseling, street children, street economy, family counseling, religious activity, income generating, literacy, reintegration into family, art, and advocacy. All of those activities are intended to prevent, to mitigate the risk, and to cope with the street children problems. All of those are carried out to meet the children's rights, whether education, survival, growth and development, or protection. When those rights have been met, the street children can function within the society.

\section{Conclusion and Recommendation}

\subsection{Conclusion}

From several approaches elaborated, it does not mean that one approach is better than another. Which approach should be selected and is appropriate, will be highly determined by the approach and problem the street children are facing. One thing needs to be remembered is that: whatever approach is chose, generally the original capital needed to manage the street children problem is our actually emphatic attitude and sincere commitment. Without both of them, it is not surprising that the street children's fate will never be resolved till to its root.

Giving social protection through advocacy, preventing the street children from being the victim of exploitative action and violence threat, through the empowering attempt combined with the improvement of relevant regulation or law, service provision consistent with the street children, as well as creating opportunity for the children in order to get their right discretionarily are the real attempts that should be collective agenda for the 
government, NGO and public society. As long as we still treat the children only as the object of program and exacerbated by the subjective interest containing economic and political content, the street children's fate will remain to be miserable in their lifetime.

\subsection{Recommendation}

So far, the attempts taken to manage the street children include to take them out of street, to enter them into "the Open House", training centers, or by catching them up, and entering them into mischievous children places; or other violence action. However, many evidence shows that the management model and implementation of caring and punitive program above cannot resolve the street children problem completely.

Coping with the street children problem till its roots does need caring programs or those program provided by the central government. The caring attitude by treating the children as charity object, giving temporary compensation and aid will only result in the street children's dependency on the pity of donor, and even it will possible nullify the street children's usefulness and self-help determination. Meanwhile, the top-down package administration in the form of massive and non-contextual program will possibly lead to some bias and deviation.

For that reason, in managing the street children, there should be an optimum coordination mechanism and system between the government, NGO, and society.

\section{References}

Adiwikarta, S. (1988). Sosiologi Pendidikan: Isyu dan Hipotesis Tentang Hubungan Pendidikan Dengan Masyarakat. Jakarta: Ditjen Dikti.

Ballantine, J. H. (2001). The Sociology of Education: A Systematic Analysis. New Jersey: Prentice Hall.

Berman, L. (1996). Interaction between street children, the State and Society. Proceedings International Conference on Street Children, Bangi Malaysia: Penerbit UKM (Universiti Kebangsaan Malaysia).

Berman, L. (2000). Surviving on The Street of Java: Homeless Children's Narratives of Violence. Discourse and Society, 11(2), 149-175. http://dx.doi.org/10.1177/0957926500011002002

BKKKS Provinsi Daerah Istimewa Yogyakarta. (1996). Proceedings International Conference on Street Children: Empowering The Street Children. Yogyakarta. Indonesia: BKKKS Provinsi Daerah Istimewa Yogyakarta.

Blackledge, D., \& Hunt, B. (1985). Sociological Interpretations of Education. London: Croom Helm.

Blerk, L. van. (2006). Diversity and Difference In The Everyday Lives of Ugandan Street Children : The Significance of Age and Gender for Understanding The Use of Space. Social Dynamics, 32(1), 47-74. http://dx.doi.org/10.1080/02533950608628719

Denzin, N. K., \& Lincoln, Y. S. (2000). Handbook of Qualitative Research. California: Sage Publication Inc.

Departemen Sosial Republik Indonesia. (1999a). Pedoman Penyelenggaraan Pembinaan Anak Jalanan Melalui Rumah Singgah. Jakarta: Departemen Sosial Republik Indonesia.

Departemen Sosial Republik Indonesia. (1999b). Petunjuk Teknis dan Pelaksanaan Pembinaan Kesejahteraan Sosial Anak Jalanan. Jakarta: Direktorat KAKLU.

Durkheim, E. (1956). Education and Sociology. New York: The Free Press.

Durkheim, E. (1961). Moral Education: A Study in the Theory and Application of the Sociology of Education. New York: The Free Press.

Faisal, S. (1987). Sosiologi Pendidikan. Surabaya: Usaha Nasional.

Hariadi, Sanituti, S., \& Suyanto, B. (1999). Anak Jalanan Di Jawa Timur: Masalah dan Upaya Penanganannya. Surabaya: Kerja sama LPA Jatim, BK3S dan Kanwil Depsos Jatim.

Horton, P. B. dan Hunt, C. L. (1984). Sociology. New York: McGraw Hill.

Irwanto dkk. (1995). Pekerja Anak Di Tiga Kota Besar: Jakarta, Surabaya, Medan. Jakarta: UNICEF dan Pusat Penelitian Unika Atma Jaya.

Irwanto, Farid, M., \& Anwar, J. (1999). Anak Yang Membutuhkan Perlindungan Khusus Di Indonesia: Analisis Situasi. Jakarta: Kerjasama PKPM Unika Atmajaya Jakarta, Departemen Sosial Republik Indonesia dan UNICEF.

Lewis, O. (1996). La Vida: A Puerto Rican Family in the Culture of Poverty, San Juan \& New York. In G. Gmelch, \& W. Zenner (Eds.), Urban Life. Long Grove: Il Waveland Press, Inc. 
Mifflen, F. J., \& Mifflen, S. C. (1986). The Sociology of Education. Calgary: Detselig Enterprises Ltd.

Mulandar, S. (Ed.). (1996). Dehumanisasi Anak Marjinal: Berbagai Pengalaman Pemberdayaan. Bandung: Kerjasama Akatiga dengan Gugus Analisis.

Nasution, S. (2004). Sosiologi Pendidikan. Jakarta: Bumi Aksara.

Parsons, T., \& Bales, R. F. (1955). Family, Socialization and Interaction Process. New York: The Free Press.

Saripudin, D, \& Ahmad, A. R. (2007). Resosialisasi Anak Jalanan Persepektif Sosiologi: Cabaran Dan Penyelesaiannya. International Conference on Life Long Learning (ICCL). Bangi Malaysia: Universiti Kebangsaan Malaysia (UKM).

Saripudin, D. (2012). The Street Children Development in Open House. Journal of Social Sciences, 8(2), 267-273.

Saripudin, D., Suwirta, A, \& Komalasari, K. (2008). Re-socialization of Street Children at Open House: A Case Study in the City of Bandung, Indonesia. EDUCARE: International Journal for Educational Studies, 1(1), 91-102.

Shalahuddin, O. (2004). Dibawah Bayang-Bayang Ancaman. Semarang: Yayasan Setara.

Silva, T. L. (1996). Community mobilization for the protection and rehabilitation of street children. Proceedings International Conference on Street Children (ICSC' 96). Jakarta: Departemen Sosial Republik Indonesia.

Suyanto, B. (2010). Masalah Sosial Anak. Jakarta: Kencana.

UNDP, \& Departemen Sosial Republik Indonesia. (1997). Pedoman Penyelenggaraan Rumah Singgah Program Uji Coba Anak Jalanan di 7 Provinsi. Jakarta: UNDP dan Departemen Sosial Republik Indonesia.

UNICEF (United Nations on International Children and Educational Fund). (1997). International Child Health: A Digest of Current Information. New York: UNICEF.

Usher, R., \& Edwards, R. (1994). Postmodernism and Education. London: Routledge. http://dx.doi.org/10.4324/9780203425206

Warsono, H., Gunarto, \& Suyanto, B. (2011). Kajian Kebijakan Sosial. Kajian Tentang Kebijakan Pendidikan (BOS), Kesehatan (JAMKESMAS) dan Perlindungan Anak di Jawa Tengah dan Jawa Timur. Semarang: UNICEF. 